\title{
Demand and supply sides of the crowdfunding ecosystem: The case of Kickstarter campaigns and potential Hungarian investors
}

\author{
ROLAND ZS. SZABÓ (1), RÉKA SZÁSZ and BORBÁLA SZEDMÁK* (1)
}

Strategic and International Management Research Centre, Corvinus University of Budapest, Budapest, Hungary

Received: November 13, 2019 • Revised manuscript received: April 14, 2021 • Accepted: April 21, 2021

Published online: May 27, 2021

(C) 2021 The Author(s)

\begin{abstract}
Crowdfunding is a disruptive innovation and has provoked interest as a new way of raising finance. The objective of our research was to analyse both the demand and supply sides of the crowdfunding ecosystem. The study used two methods. The first was a database analysis of 259,114 Kickstarter campaigns. The second was a survey on public awareness of crowdfunding in Hungary, from the perspective of 132 potential investors. The findings suggest several success factors that may be useful for campaign launchers: (1) appealing project presentation; (2) diverse pool of rewards; (3) realistic set of funding goals; (4) appropriate categories and sums of pledges; and (5) frequent communication and satisfactory information about the campaign. Furthermore, the study revealed the differences between the potential investors' expectations and the reality of crowdfunding practices.
\end{abstract}

\section{KEYWORDS}

crowdfunding, financing, investor expectations, funding goal, platform

JEL CODES

M13, 016

*Corresponding author. E-mail: borbala.szedmak@uni-corvinus.hu 


\section{INTRODUCTION: THE EMERGENCE OF CROWDFUNDING}

Crowdfunding, as a new and alternative method of financing, is growing in popularity around the world (cf. Wilson et al. 2017). This form of financing first appeared in the United States where it still has the largest market. Most of the campaigns originate from the USA and the success rate is also the highest there compared to other countries (Kuti - Hornyák 2017). The Central European region - including Hungary - is far behind the USA and the Western-European countries as well in terms of market share (Juhász 2018). It is therefore important to examine the possibilities of crowdfunding for the Hungarian pool of potential investors. The objective of this research was to analyse both the demand and supply sides of the crowdfunding ecosystem.

To provide a theoretical overview of the field of crowdfunding, this article gives an overview of existing definitions and places the phenomenon in a financial structure. After outlining and comparing the different models of crowdfunding, we detail the characteristics of crowdfunding platforms and introduce some success factors identified in the crowdfunding literature, followed by an examination of the phenomenon as a social innovation.

This study used two separate methods. We used a survey to examine public awareness of crowdfunding in Hungary and approaches, preconceptions and motivations of potential future investors in the market. We assumed that the best known and preferred model for Hungarian investors of the four models of crowdfunding would be the Reward-based model. We therefore opted to analyse 259,114 campaigns on Kickstarter, as the most globally-recognised crowdfunding platform, using the CrowdBerkeley Database. The article finds that in order to succeed, campaigners need to choose the appropriate pledge amounts and categories, give updates regularly, provide a well-designed landing page and include a video as well. It should also be highlighted that the least successful campaigns have more unrealistic expectations. The research findings suggest that - based on the most successful and unsuccessful campaigns - the number of FAQs, the existence of a video and the number of backers affect the amount of money raised.

\section{LITERATURE REVIEW}

Crowdfunding originated from crowdsourcing and does not yet have a widely accepted definition in the academic literature. According to Belleflamme, Lampert and Schienbacher (2014: 588.) "crowdfunding involves an open call, mostly through the Internet, for the provision of financial resources either in the form of donation or in exchange for the future product or some form of reward to support initiatives for specific purposes".

Other authors emphasise the collective nature of crowdfunding (Ordanini et al. 2011), where a group of individuals takes over the role of professional investors (Schwienbacher - Larralde 2012; Forbes - Schaefer 2017). As the need for intermediaries disappeared, crowdfunding platforms emerged to connect the parties involved (Kuti - Madarász 2014). Another significant feature of this new phenomenon is that it can be an effective alternative for financing (new) businesses (Mulcahy 2013; Paschen 2017) - often with better terms than traditional solutions (Katona 2019).

After analysing several existing definitions, Hossain and Oparaocha (2017: 4.) provided an extensive summary of crowdfunding: 
Crowdfunding is an Internet-based funding method for the realization of an initiative through online distributed contributions and micro-sponsorships in the form of pledges of small monetary amounts by a large pool of people within a limited timeframe. It is the financing of a task, idea, or project by making an open call for funding, mainly through Web 2.0 technologies, so funders can donate, pre-purchase the product, lend, or invest based on their belief in an appeal, the promise of its founder, and/or the expectation of a return.

Crowdfunding helps validate the idea by getting real consumer feedback which can be beneficial later when negotiating with business angels and venture capital funds (Ferke et al. 2016). Furthermore, it is an effective marketing and networking tool (Durgula et al. 2017) and it also helps campaigners supplement domestic funds with international resources (Kuti et al. 2018). Thanks to information technology, it solves the problem of geographical distance, however, cultural differences and information asymmetry between the campaigner and the investors can cause challenges (Kuti - Hornyák 2017). The lack of personal contact, the online operation of the platforms and thus the lower level of trust are also barriers that the ecosystem has to overcome (Bethlendi - Végh 2014; for a complex summary of the advantages and risks of crowdfunding see Durgula et al. 2017: Figure 1).

\subsection{Crowdfunding and financial structure}

Going beyond the traditional capital sources of business angels, venture capital or private equity, new 'players' have recently emerged in the field of entrepreneurial finance. The different crowdfunding options and models are important parts of these new sources. Block et al. (2017) described a number of new players: accelerators (and incubators), angel networks, crowd (debt-, donation-, reward- and equity-based), corporate venture capital (CVC), family offices,

\section{Where Crowdfunding Fits on the Funding Lifecycle}

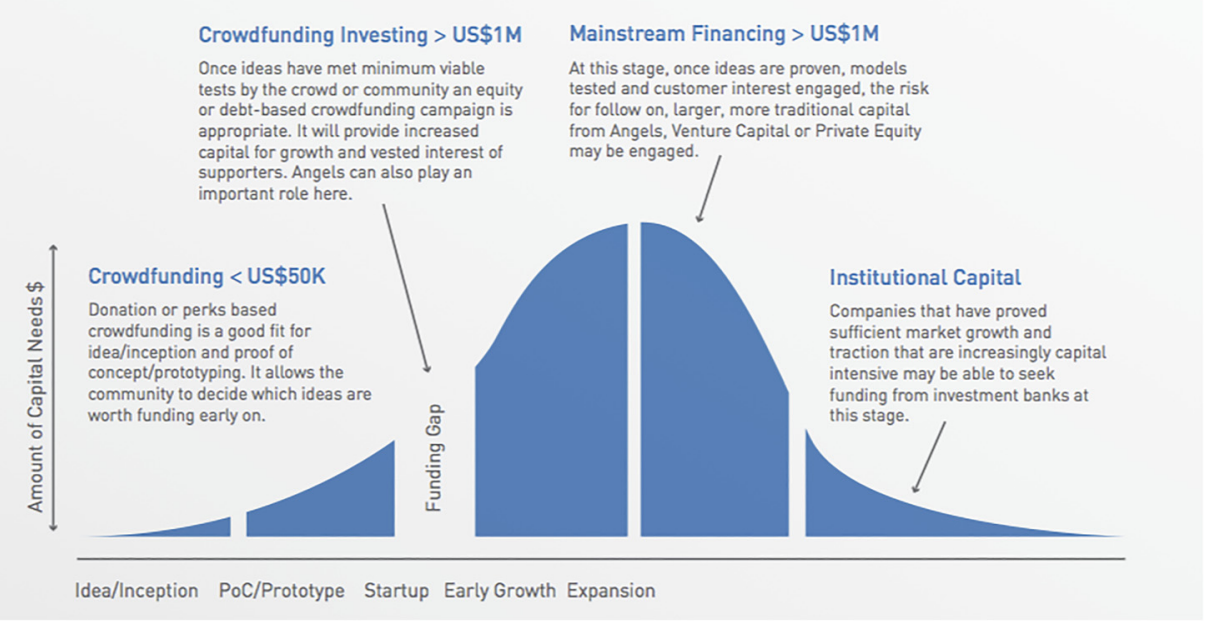

Source: infodev (2013: 16)

Fig. 1. Crowdfunding adoption curve. Source: infoDev, 2013 
governmental venture capital (GVC), IP-based investment funds, IP-backed debt funding, minibonds, social venture funds or social venture capital, university-managed or university-based funds, and venture debt lenders or funds.

After the global economic crisis, the funding capacity of the banking sector decreased, which particularly affected smaller companies, and meant there were more limited options for obtaining funding. It is therefore likely that the original crowdfunding model will change in the next few years to focus more on profit-oriented initiatives (Gábossy 2016).

We also have to differentiate between the amounts of capital needed. If we are talking about larger amounts, more substantial institutions (e.g. banks or venture capital funds) are available. For smaller initiatives, however, the possibilities are more limited (Danmayr 2014). Crowdfunding can also be linked to the microfinance ecosystem, as one of its main areas of focus is to obtain funds from the crowd (Armstrong et al. 2018).

The curve in Figure 1 shows how and where exactly crowdfunding fits into the funding lifecycle of a new business. The two axes show the amount of capital needed in USD and the stage of the lifecycle from idea/inception to expansion.

Different types of crowdfunding can be used in nearly every stage of the creation of a new business, but the most serious impact can be made in the so-called 'Funding Gap'. This is the stage when startups need the biggest financial boost, so targeted crowdfunding goals are usually over one million USD.

\subsection{Crowdfunding models}

The academic literature identifies four main crowdfunding models: donation-based, rewardbased, equity-based and lending-based. Total crowdfunding volume grew to an immense 34.44 billion USD in 2015, more than double the previous year's total (CrowdExpert 2018). From the breakdown, the lending model was the most popular, providing 25.1 billion USD, with donations providing 2.85 billion USD, rewards 2.68 billion USD and the equity modell 2.56 billion USD. Two minor models can also be identified, royalty-based, providing 405 million USD and hybrid, with 811 million USD.

Donation-based crowdfunding is the simplest model, where social and altruistic aspects counterbalance profit-seeking. Funders tend to follow and support causes that are important to them. Supporters do not receive any 'material' reward, but may get symbolic returns from time to time (Hossain - Oparaocha 2017). Projects on renewable solutions, attracting a 'green crowd', tend to be launched on donation- or reward-type platforms (Vasileiadou et al. 2015).

The main idea behind the reward-based crowdfunding model is that the founder offers 'material' incentives for everyone supporting their campaigns. Smaller and larger contributions are usually distinguished by different levels of rewards. Based on the value of their support, backers receive a wide variety of incentives, ranging from t-shirts to tickets to a launch party (Cox - Nguyen 2018). If the project succeeds, backers may also typically receive the products themselves, so this can be seen as a form of preselling. Several reward-based campaigns have been the (first) actions of entrepreneurs whose most important goal is to move their products, which are usually very innovative or technology-based, into the mass market (Roma et al. 2017). The reward-based model is most likely of all the models to be linked to the phenomenon of crowdventuring, which aims to foster entrepreneurial activities, such as creating new products or services drawing on the intelligence of the crowd (Elia - Margherita 2018). 
Table 1. Comparison of crowdfunding models

\begin{tabular}{|l|c|c|c|c|}
\hline Models & Donation-based & Reward-based & Equity-based & Lending-based \\
\hline Model Type & $\begin{array}{c}\text { Patronage/ } \\
\text { Charity }\end{array}$ & Donation/'Pre-selling’ & (Micro)investments & (Micro)loans \\
\hline Nature of Projects & $\begin{array}{c}\text { Mostly art or } \\
\text { humanitarian } \\
\text { projects }\end{array}$ & Mostly entrepreneurial & Various & Various \\
\hline Position of Funders & Philanthropists & Early customers & Investors & Lenders \\
\hline Return for Funders & $\begin{array}{c}\text { No direct return/ } \\
\text { Intangible } \\
\text { benefits }\end{array}$ & $\begin{array}{c}\text { Intangible benefits/ } \\
\text { Rewards }\end{array}$ & $\begin{array}{c}\text { Equity stakes/ } \\
\text { Shares of future } \\
\text { profits or royalties }\end{array}$ & $\begin{array}{c}\text { Funds are loans: } \\
\text { some rate of return } \\
\text { on capital invested }\end{array}$ \\
\hline
\end{tabular}

Source: authors, based on Mollick (2014).

The Crowdfund Act of the Jumpstart Our Business Startups (JOBS) Act, signed by President Barack Obama, first enabled equity-based crowdfunding to broaden funding opportunities in the United States (Stemler 2013). The backers of equity-based crowdfunding projects play the role of investors. In return for their monetary contributions, they receive equity stakes. This can be an effective element of the funding strategy (Belleflamme et al. 2015). The origins of equity crowdfunding (or 'crowdinvesting') go back to corporate funding.

According to Harriet et al. (2017), the CEOs launching this type of campaigns consider equity crowdfunding largely as a useful marketing tool, because it is important to them that they are not giving away their autonomy in decision-making. Entrepreneurs usually choose this kind of model in the case of bigger, more resource-intensive projects (Kuti et al. 2017). Turan (2015) examined the level of risks for all those involved during the different stages of an equity-based crowdfunding campaign, and found that investors bear the highest risk and entrepreneurs and campaigners the lowest.

Backers using the lending-based-also known as debt-based-crowdfunding model act as moneylenders. The development of 'FinTech' has allowed peer-to-peer lending and therefore created lending-based crowdfunding. The revolutionary aspect of peer-to-peer solutions is that they allow those involved to cut out intermediaries, typically banks, and therefore make investing more profitable for all participants. The original concept is to connect directly those who have money for investment/lending purposes and those who need financial support (Fleming - Sorenson 2016). Table 1 shows a comparison of the four models, and summarises their main differences.

\subsection{Crowdfunding platforms}

2.3.1. Platforms as business models. Conceptualizing business models, it is undeniable that multi-sided platforms or multi-sided markets have a specific structure. The existence of these platforms is not a new phenomenon, but their range and importance have increased with the expansion and development of information technologies (Csontos - Szabó 2018). 
Following the logic of the building blocks of the business model canvas, the main value proposition of multi-sided platforms is connecting and facilitating the interactions of (two or more) different customer segments. These customer segments are interdependent groups, meaning that value is only created if both parties are present. Serving all actors simultaneously, platforms can create value by expanding the circle of users, leading to the so-called network effect. Multi-sided platforms can also be linked to free business models, because platform operators may consider attracting certain customer segments by offering them free value propositions (Osterwalder - Pigneur 2010).

2.3.2. The crowdfunding ecosystem. The crowdfunding 'ecosystem' includes three main groups: the campaigners, the backers and the crowdfunding platforms. The relationships and links between these three main stakeholders form a complex system (Valanciene - Jegeleviciute 2014). Campaigners, fundraisers, and entrepreneurs publish and launch their projects on a chosen crowdfunding platform in the hope of financial support. They aim to target and reach potential customers, which is not an easy job, so they have to make an effort to keep potential funders' attention by making their campaigns attractive (Scholz 2015). On the other side of the equation is the backer, or the 'crowd' of the crowdfunding phenomenon. Depending on the crowdfunding model, this group will obtain some kind of remuneration in exchange for monetary contributions. Originating from crowdsourcing, the intelligence or 'wisdom' of the crowd opened the gates for several crowd-based business models that may provide competitive advantages for entrepreneurs (Tauscher 2017). However, Wilson et al. (2017) warned against neglecting the issues related to crowdthink and crowd hijacking. Consumers can enrich and develop their identity values as a result of participating in creative crowds (Fedorenko et al. 2017).

The third party of this ecosystem is the crowdfunding platform that serves as an intermediary, creating value by connecting the other two groups. Operating a platform provides opportunities for user-generated (occasionally niche) products, services and content. A platform can only be successful and sustainable if it fits into the entrepreneurial ecosystem organically and thus has a "gravity effect": it is able to attract quality projects (Kuti - Bedö 2016). However, creating a platform is not enough: creating a culture that supports this kind of funding, building trust and educating people about crowdfunding are also essential. According to the research of Kuti and Bedö (2018), those students who took part in an incubation program are more likely to take part in a crowdfunding campaign.

We identified campaign-launching entrepreneurs as the supply side of crowdfunding, supplying different types of investment opportunities for backers. The demand side of crowdfunding are the potential crowdfunding campaign backers seeking different types of rewards.

\subsection{Success factors in the crowdfunding literature}

A few studies have focused on the factors that can improve success in crowdfunding campaigns, although the literature is far from complete. Chen et al. (2016) examined crowdfunding campaigns from a promotional point of view, focusing on the tools used in marketing and marketing communications. They organized the 'antecedents' of campaign success into three main categories (see Table 2) and identified factors that may improve campaign success and encourage donations if used appropriately.

Forbes and Schaefer (2017) also identified some guidelines for successful crowdfunding. They highlighted the importance of choosing the right platform, setting the funding goal 
Table 2. 'Antecedents' of crowdfunding campaign success

\begin{tabular}{|l|c|}
\hline \multirow{4}{*}{ 1. Appeal modes } & Guilt appeals \\
\hline \multirow{2}{*}{ 2. Product characteristics and message frames } & Self-benefit and others-benefit appeals \\
\cline { 2 - 2 } & Product type (utilitarian vs. hedonic products) \\
\cline { 2 - 2 } & $\begin{array}{c}\text { Message frames ('rational' vs. 'emotional' message } \\
\text { frame) }\end{array}$ \\
\hline \multirow{3}{*}{ 3. Presentation characteristics } & Length of video and textual pitch \\
\cline { 2 - 2 } & Professionalism \\
\cline { 2 - 2 } & Image valence \\
\cline { 2 - 2 } & Reward tiers \\
\cline { 2 - 2 } & Funding period \\
\cline { 2 - 2 } & Funding goal \\
\cline { 2 - 2 } & \\
\cline { 2 - 2 } &
\end{tabular}

Source: authors, based on Chen et al. (2016).

appropriately (for example, to set the lowest possible funding goal to exploit the 'green bar effect'), choosing the right reward options (tangible reward options are preferable) and thinking about the content, presentation and structure of the campaign video.

The 'social capital' of fundraisers can also be a significant factor in the likelihood of success. Campaigners are advised to use and activate all their available social contacts and relationships to increase awareness of their campaign and therefore strengthen the chances of success (Buttice et al. 2017). According to Lee and Shin (2018), the growth of crowdfunding and peer-to-peer lending communities can be effectively supported using social media. There are therefore a number of factors to take into account before launching a crowdfunding campaign.

\section{RESEARCH DESIGN AND METHODS}

This study used two main research methods. The first focused on a database analysis of 259,114 Kickstarter campaigns, and the second consisted of a survey examining public awareness of crowdfunding.

\subsection{Database analysis of Kickstarter campaigns}

We used the Haas-Berkeley Crowdfunding Website and particularly their CrowdBerkeley Database (Haas-Berkeley Crowdfunding Website 2016). As the world's leading research initiative for crowdfunding, CrowdBerkeley was developed by three institutes: the Fung Institute for Engineering Leadership, the Haas School of Business Finance Group and the Institute for Business \& Social Impact at Haas School of Business (CrowdBerkeley website, 2018), which built the database together. Registered researchers can use it to explore campaigns hosted on six 
global crowdfunding platforms (Kickstarter, Indiegogo, Rockethub, FundRazr, Lending Club, and Kiva) between 2005 and 2016.

We downloaded data files for all Kickstarter campaigns between 2012 and 2016. We chose Kickstarter because it is one of the most well-known and popular crowdfunding platforms and so has the highest number of projects. A total of 259,114 Kickstarter campaigns were analysed. We specifically looked at:

- How many projects were launched each year, how many of them were successful and how many of them were failed?

- How much was the average amount invested?

- Which projects were the most successful by gathering the most funding each year?

- What was the difference between the most successful projects and the failed projects?

Measures used for defining the difference between the most successful projects and the failed projects included the following:

- successful projects: campaigns that could reach or even exceed the funding goal (dummy variable, 0: unsuccessful, 1: successful);

- pledged goal: the amount of money requested (USD);

- gathered: the amount of money raised (USD);

- backers: number of supporters;

- FAQs: number of frequently asked questions;

- updates: number of updates (posts) of the campaigner on the landing page;

- comments: number of comments posted by backers on the landing page of the campaign;

- number of pledges: how many types of pledges are available and can be chosen when supporting the campaign;

- minimum pledge (USD): the minimum amount of money that can be given for supporting the project;

- maximum pledge (USD): the maximum amount of money that can be given for supporting the project;

- video: whether there is a video about the campaign on the landing page (dummy variable, 0 : no video, 1: the page includes a video);

- landing page design: design of the page measured on a Likert scale of 1-5 (1: the page is not appealing at all, 5: perfectly designed page).

\subsection{Crowdfunding survey}

We used a survey from Forbes (2015) as the basis for the structure of our survey. We adapted the survey to include some additional questions and modifications. To make the logical structure of the questions easier to follow, they were grouped into sections:

- information on the participant;

- awareness of crowdfunding;

- engagement in crowdfunding;

- reasons for not investing;

- the experience of an investor;

- crowdfunding model preferences (new section); and

- future investment. 
The most significant additions were to add a new answer option to the section 'Engagement in crowdfunding', to allow respondents to choose a non-existent platform. We also added a question about whether the participants are members of any forums or knowledge-sharing communities focusing on crowdfunding, and if yes, asked them for the name(s) of the group(s). Both investors and non-investors were asked new questions about the smallest and largest amounts of money that could be invested in a campaign, to explore their knowledge about the financial aspects of crowdfunding. We also added a new section to examine the preferences of all participants for different crowdfunding models.

The language of the survey was English, as a conscious filter criterion. The survey was first filled out by a test group of seven, and the survey was then distributed via different social media channels over a time period of 20 days, resulting in a total of 132 participants from both Hungary $(84 \%)$ and elsewhere (16\%). We specifically looked at the potential investors' expectations.

At the time of the questionnaire survey, the awareness of crowdfunding, the investment intentions and opinions of potential Hungarian investors are well represented by the research. Twothird of the respondents has a C1 or C2 level of proficiency in English or a native speaker. The average age of the participants is 26.9 years. $64 \%$ are $18-25$ years old, $18 \%$ are $26-35$ years old and $18 \%$ older than 35 years. $44 \%$ of the sample is male and $56 \%$ is female. $70 \%$ of the sample has tertiary education. $51 \%$ of the sample lives in Budapest, $11 \%$ in Pest County and $38 \%$ elsewhere. The survey represents the opinions of the potential Hungarian target market of crowdfunding campaigns; English speaking young adults with tertiary education living in Central Hungary.

\section{RESEARCH FINDINGS}

\subsection{Database analysis of Kickstarter campaigns}

Figure 2 shows all projects launched on Kickstarter in the five-year period. The columns show the proportion of successful ('Successful') and unsuccessful ('Failed') campaigns over the years.

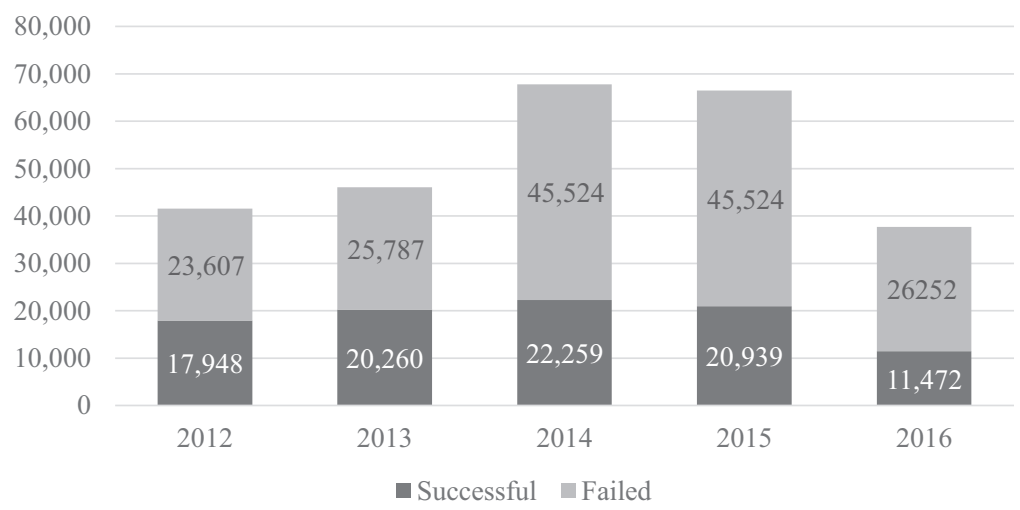

Source: CrowdBerkeley Database

Fig. 2. Total number of projects launched on Kickstarter, 2012-2016 
The number of campaigns increased from 2012, reaching its highest point in 2014, when 67,783 projects were launched. A year later, in 2015 , there were 66,005 in total. The final year of the sample, 2016, is a special case, because the database only contained data for the first nine months of the year, so the total number of projects is expected to be higher than 37,724 . Two sub-categories of successful projects were distinguished. 'Reached' projects raised precisely the campaign funding target. 'Exceeded' projects raised more than the funding goal. The numbers clearly show that successful campaigns usually exceed their funding targets.

Figure 3 shows the detailed situation of the funding goals and the amounts of money raised. The average funding target rose year-on-year, but the average raised remained similar. This may indicate changes in attitude by campaign launchers or it could also indicate that there are only a limited number of investors (still), with a limited amount of funding, so they are simply picking the best projects. This is particularly likely if funded projects generally exceeded their goals.

The monthly analysis of campaign launches suggests that the start date of a campaign could affect the success of a project. The most successful month of the year to launch a campaign was February in 2012, 2013 and 2014 and the least successful was December in 2012, 2013 and 2015. This may be because people, including potential investors, do not tend to spend large sums of money leading up to Christmas. These findings suggest that project owners should avoid launching campaigns at the end of the year, and actively consider a start date in February.

The overall percentage of successful campaigns (in a monthly breakdown) decreased throughout the period. This may be the result of disillusionment in crowdfunding, also signalled by the reduction in the overall volume of new projects in 2016 on all dominant platforms, with 16\% fewer campaigns launched overall in 2016 than in 2015 (James 2017).

Comparing the 25 most successful campaigns each year with the 25 most unsuccessful ones, it turns out that the number and frequency of updates by campaigners seems to affect the success $\left(\rho_{\mathrm{FAQs}}=0.869, \mathrm{p}<0.01, \rho_{\text {updates }}=0.916, \mathrm{p}<0.01, \rho_{\text {comments }}=0.923, \mathrm{p}<0.01\right)$. In order to

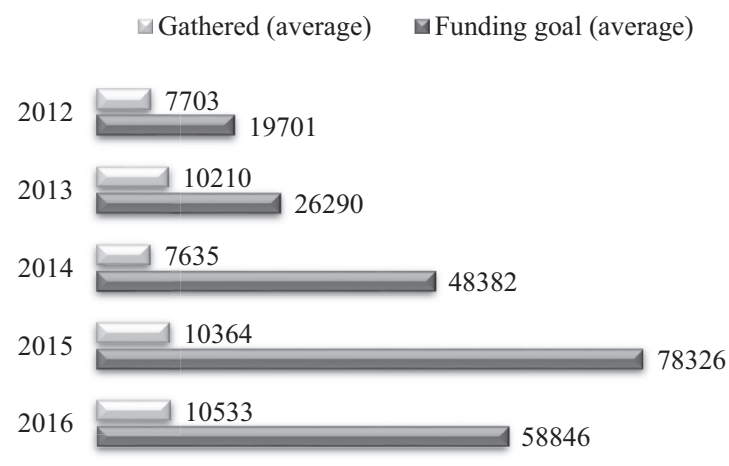

Source: CrowdBerkeley Database

Fig. 3. Funding goals vs. gathered amounts (in USD) 
Table 3. Measures defining the success of a campaign

\begin{tabular}{|l|c|}
\hline & Standardized Beta \\
\hline Pledged goal & -0.007 \\
\hline FAQs & $0.194^{* *}$ \\
\hline Updates & 0.020 \\
\hline Comments & 0.007 \\
\hline Number of pledges & 0.051 \\
\hline Minimum pledge (USD) & -0.019 \\
\hline Maximum pledge (USD) & -0.096 \\
\hline Video & $0.195^{* *}$ \\
\hline Backers & $0.553^{* * *}$ \\
\hline
\end{tabular}

*** The value is significant at the 0.01 level.

Source: authors.

succeed, campaigners also need to choose the appropriate pledge amounts $\left(\rho_{\text {minimum pledge }}\right.$ (USD) $\left.=-0.267, \mathrm{p}<0.01, \rho_{\text {maximum pledge (USD) }}=0.131, \mathrm{p}<0.05\right)$ and categories $\left(\rho_{\text {number of pledg- }}\right.$ es $=0.643, \mathrm{p}<0.01)$ to attract the most backers $\left(\rho_{\text {backers }}=0.926, \mathrm{p}<0.01\right)$. The 'best' projects typically offered actual products that could be topped up with experiences in the upper pledge categories. The overall appearance and structure of the campaign description is important ( $\left.\rho_{\text {landing page design }}=0.894, \mathrm{p}<0.01\right)$, and a video has become essential in crowdfunding campaigns $\left(\rho_{\text {video }}=0.574, \mathrm{p}<0.01\right)$. It was also clear that the least successful campaigns have more unrealistic expectations $\left(\rho_{\text {pledged goal }}=-0.789, \mathrm{p}<0.01\right)$.

Based on the most successful and unsuccessful campaigns, the number of FAQs, the existence of a video and the number of backers affect the gathered amount of money (see Table 3).

\subsection{Crowdfunding survey}

The largest share of the respondents to our survey, 44\%, were between the ages of 21 and 25, and the majority of the sample was female. The biggest group had either a Bachelor's or Master's degree, and $16 \%$ worked in the field of management. The survey reached international applicants, who made up $16 \%$ of the sample. The vast majority, however, were from Hungary's capital, Budapest. We used online distribution to target the same group as crowdfunders, targeting the same audience that project creators tend to reach. This suggests that campaigners need to take conscious steps to satisfy the needs of this audience.

The language of the survey was a filter criterion, as we expected the majority of participants to be confident in English, and $66.7 \%$ had a $\mathrm{C} 1$ or higher level of proficiency. This indicates that potential investors generally have an adequate level of English to be fully involved in crowdfunding. However, it is important to ask how this circle can be widened, especially in Hungary. 
The majority of respondents had heard of crowdfunding, including across four out of the seven separate age categories between the ages of 18 and 35. The majority of both men and women had heard the term, but men were more likely to have done so (69\% vs. $58 \%$ of women). In total, $71 \%$ of those with a Bachelor's degree and $67 \%$ with a Master's degree had heard of crowdfunding. Awareness may therefore be linked to both gender and education levels, which might affect campaign, content and marketing choices of fundraisers. It may also be necessary to educate potential future investors about crowdfunding to expand the reach of campaigns. Examining the links between crowdfunding awareness and location, 57\% of those from Budapest and 53\% from the countryside had heard the term, but only $13 \%$ of participants living abroad had not. This suggests that international participants are more aware of the phenomenon than those who live in Hungary.

Participants tended to be aware of far more platforms than they had visited, with a reduction of $36 \%$ from recognition to visiting. There was an even greater reduction of $84 \%$ from visiting to investment. This shows that campaigners should choose their platform carefully, and also ensure that their projects capture and hold the attention of potential investors. Participants were far more likely to recognise Kickstarter than other platforms, which suggests that projects launched on this platform may have more chance of success. It is interesting that six participants claimed to recognise the non-existent PeopleFunding platform and four claimed that they had visited it. It is possible that people who are less familiar with crowdfunding may confuse the names of lesser-known platforms.

Participants were asked why they had not invested in a crowdfunding campaign. The most frequent answer, from $29.6 \%$, was 'No projects have appealed'. The second most common response was 'Not enough information about the product/service', from 16.8\%. Other significant options chosen were 'Too high a risk of no return' and 'No appealing reward option'. This suggests that project creators have to focus on these factors. It is also important to examine the opinion of non-investors about the smallest and largest amounts of money required to invest in a campaign, because that can indicate preconceptions. The majority gave a range of 1-10 USD as a minimum investment, but some surprisingly high sums were also given. The majority agreed that there was no maximum limit.

Only $9.8 \%$ of the sample had ever invested in a crowdfunding campaign, so we cannot draw any reliable conclusions from their investment experiences. It seems likely that most of them had only invested once. Although the number of investors was quite small in the sample, it was still unexpected that a large proportion, $46.2 \%$, were 'not at all' satisfied with their investment experience.

We asked about the likelihood of investing in different crowdfunding models, with 10 being very likely and 1 being not likely at all. For the donation-based model, the average likelihood was 6.65 out of 10, for the reward-based, it was 6.7, for the equity model, it was 6.01 and finally, the lending-based model had an average of 5.36. Looking purely from an investment angle, this suggests that the reward-based model is preferred by Hungarian potential investors. No previous study has fully explored investor preferences for particular crowdfunding models, so this is an important addition to the field and also a suitable avenue for future work.

Finally, the majority of the sample does not seem likely to invest in the future, given the average answer of 4.98 out of 10 to this question (where 10 is very likely). This indicates the current overall attitudes of potential investors in the Hungarian market. 


\subsection{Synthesis of the research findings}

4.3.1. Investors' expectations vs. average invested amounts. This section compares the opinions of non-investor survey participants about the smallest and largest amounts necessary to contribute with the average amount of money invested per backer from the database. Of the 132 participants of the survey, 119 had never invested in a crowdfunding campaign, but only 115 people gave a numerical or applicable answer to these questions. We assessed a logarithmical scale of the 'investable' amounts in USD (see Table 3).

The first row ("MIN") shows the number of participants divided into ranges by their opinion about the smallest amount of money needed to invest in a crowdfunding campaign. For example, 41 participants $(35.65 \%$ of 115$)$ stated that the minimum amount of money required was between 0 and 1 USD, and only one person (0.87\%) gave an amount between 100,000.01 and one million USD.

The "MAX" row shows the number and percentage of participants by their views on the largest amount that could be invested in crowdfunding. The percentages are skewed towards larger sums of money, and a significant number of participants (40\%) answered that more than one million USD could be invested into a campaign, with most saying that the maximum amount was 'unlimited'. The next five rows of Table 4 show the distribution of the average invested amounts per backer between 2012 and 2016 in USD. For example, in 2016, 27.17\% of backers invested an amount between 100.01 and 1,000 USD.

Figure 4 shows differences between the expectations of potential investors about the minimum and maximum investable amounts and the 'reality', the average invested amount per backer in 2016. The vast majority, 71.19\%, of the invested amounts were between 10.01 and 100 USD, with $27.17 \%$ between 100.01 and 1,000 USD. The same tendency was also visible in previous years.

4.3.2. Success factors for crowdfunding campaigns. By examining public awareness and approaches towards crowdfunding with the help of our crowdfunding survey, we were able to outline the 'consumer profile' of a potential crowdfunding investor in Hungary. This person is male, between the ages of 21 and 25 with a Bachelor's or Master's degree, living in the capital city. As the language of the survey was a conscious filter criterion, it is also expected that the investor of the future will be a confident English speaker.

Taken together, the findings suggest a number of success factors that may be useful for campaign launchers:

- an appealing project presentation;

- a diverse pool of rewards;

- a realistic set of funding goals;

- appropriate categories and sums of pledges; and

- frequent communication and satisfactory information about the campaign.

Some factors are consistent with those identified in previous studies. For example, the 'appealing project presentation' is similar to Chen et al.'s (2016) 'presentation characteristics' and the 'realistic set of funding goals' matches Forbes and Schaefer's (2017) 'setting the funding goal'. The research of Kuti et al. (2017) highlights the importance of 'campaign activity' and regular updates which appears in our research as 'frequent communication and satisfactory information about the campaign'. 
Table 4. Investors' expectations vs. average invested amounts

\begin{tabular}{|l|c|c|c|c|c|c|c|c|}
\hline USD & $\mathbf{0 - 1}$ & $\mathbf{1 . 0 1 - 1 0}$ & $\mathbf{1 0 . 0 1 - 1 0 0}$ & $\mathbf{1 0 0 . 0 1 - 1 , 0 0 0}$ & $\mathbf{1 , 0 0 0 . 0 1 - 1 0 , 0 0 0}$ & $\mathbf{1 0 , 0 0 0 . 0 1 - 1 0 0 , 0 0 0}$ & $\mathbf{1 0 0 , 0 0 0 . 0 1 - 1 , 0 0 0 , 0 0 0}$ & $\mathbf{1 , 0 0 0 , 0 0 0 . 0 1 - \infty}$ \\
\hline \multirow{2}{*}{ MIN } & 41 & 37 & 25 & 5 & 4 & 2 & 1 & - \\
\cline { 2 - 9 } & $35.65 \%$ & $32.17 \%$ & $21.74 \%$ & $4.35 \%$ & $3.48 \%$ & $1.74 \%$ & $0.87 \%$ & - \\
\hline \multirow{2}{*}{ MAX } & 2 & 2 & 7 & 17 & 14 & 17 & 10 & 46 \\
\cline { 2 - 9 } & $1.74 \%$ & $1.74 \%$ & $6.09 \%$ & $14.78 \%$ & $12.17 \%$ & $14.78 \%$ & $8.70 \%$ & $40.00 \%$ \\
\hline 2016 & $0.02 \%$ & $0.92 \%$ & $71.19 \%$ & $27.17 \%$ & $0.70 \%$ & $0.01 \%$ & - & - \\
\hline 2015 & $0.09 \%$ & $1.19 \%$ & $68.54 \%$ & $29.63 \%$ & $0.54 \%$ & - & - & - \\
\hline 2014 & $0.08 \%$ & $1.55 \%$ & $72.35 \%$ & $25.71 \%$ & $0.31 \%$ & - & - & - \\
\hline 2013 & $0.005 \%$ & $0.54 \%$ & $76.45 \%$ & $22.84 \%$ & $0.16 \%$ & - & - & - \\
\hline 2012 & $0.01 \%$ & $0.32 \%$ & $78.00 \%$ & $21.59 \%$ & $0.08 \%$ & - & & - \\
\hline
\end{tabular}

Source: authors and CrowdBerkeley Database. 


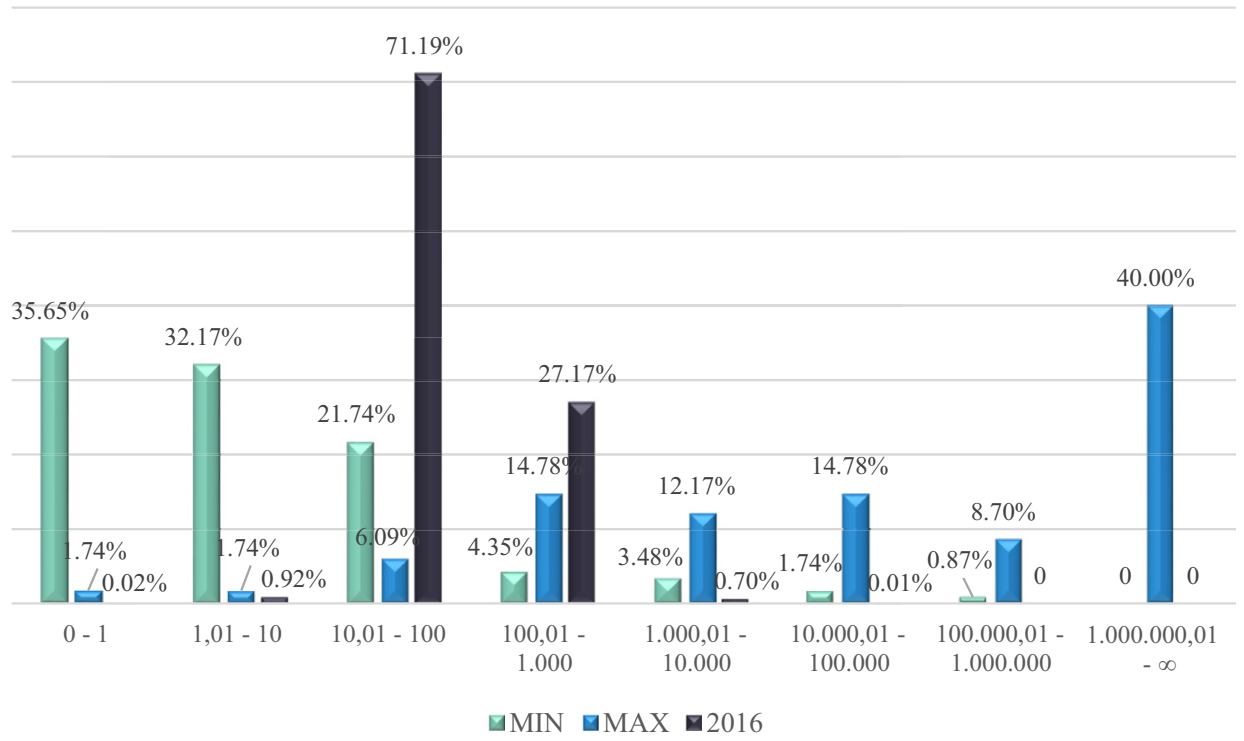

Source: authors and CrowdBerkeley Database

Fig. 4. Investors' expectations vs. average invested amounts in 2016

\section{FINAL THOUGHTS AND FUTURE RESEARCH RECOMMENDATIONS}

This work has a number of policy implications. These include the importance of educating people about crowdfunding, the use of regulation to encourage it, and possible future tax allowances. The work also has implications for entrepreneurs and managers, and may help entrepreneurs to reach early buyers and gain proof of concept much sooner.

The research however has some limitations. We only examined one part of the global supply side and used a Hungarian sample for the demand side of the crowdfunding ecosystem, so the results may not be fully generalizable to other countries. The number of participants in the survey was also relatively small, but this is partly explained by the low awareness of crowdfunding at the time of the research.

Future researchers might further examine the crowdfunding model preferences of potential investors in Hungary. They could also analyse the context of failed crowdfunding campaigns with special emphasis on the differences between projects with zero backers and those with a few supporters. Other studies might examine campaign success during a period of 'crowdfunding education'. For a better understanding of the managerial implications, future studies should analyse more crowdfunding campaigns focusing on the success factors. Future research could examine the communities involved in crowdfunding Facebook Groups or other knowledge-sharing forums focusing on crowdfunding. It may also be interesting to research whether smart contracts using blockchain technology or investing in blockchain tokens will have any effect on the dynamics of crowdfunding platforms in the future, 
particularly because they guarantee equal opportunities to participate in early-stage investments (Chen 2018).

\section{CONCLUSIONS}

As a disruptive innovation, crowdfunding appeared to be an intriguing new way to raise capital. In Hungary, however, the awareness and popularity of crowdfunding are in an initial phase of growth (Juhász 2018), which affects the likelihood of future investment. In Hungary there were several initiatives to set up a Hungarian crowdfunding platform, however, they have failed (e.g. indulj.be), thus small, local, Hungarian language platforms are not a viable option. It may be necessary for governments or organisations to take steps to inform and educate potential Hungarian investors about the crowdfunding phenomenon and the opportunities it offers to expand the circle of future investors. It may also be helpful to eliminate the language barrier posed by of lack of English and raise awareness among potential investors living in rural areas. Crowdfunding is a social innovation that supports the development of intelligent, sustainable, and inclusive society, however, it is a risky way to invest or lend, as it is not regulated (e.g. in Hungary), nor supervised. Economic relations are emerging and shifting in a brand-new way, and the organizational methods of entrepreneurs, innovators and new buyers are also affected. This new funding model therefore actively supports both the development and spread of technological innovations and the fulfilment of social innovation in a novel way. We suggest that crowdfunding could be an important tool for economic stimulus and could revitalize both the entrepreneurial and investment cultures.

\section{ACKNOWLEDGEMENT}

This research was supported by the project EFOP-3.6.2-16-2017-00007, entitled "Aspects on the development of intelligent, sustainable and inclusive society: social, technological, innovation networks in employment and digital economy". The project has been supported by the European Union, co-financed by the European Social Fund and the budget of Hungary.

\section{REFERENCES}

Armstrong, K. - Ahsan, M - Sundaramurthy, C. (2018): Microfinance Ecosystem: How Connectors, Interactors, and Institutionalizers Co-Create Value. Business Horizons 61(1): 147-155.

Belleflamme, P. - Lambert, T. - Schwienbacher, A. (2014): Crowdfunding: Tapping the Right Crowd. Journal of Business Venturing 29(5): 585-609.

Belleflamme, P. - Omrani, N. - Peitz, M. (2015): The Economics of Crowdfunding Platforms. Information Economics and Policy 33(12): 11-28.

Bethlendi, A. - Végh, R. (2014): Közösségi finanszírozás - valós lehetőség-e a hazai kisvállalatok számára? [Crowdfunding - is it a Real Opportunity for Hungarian Small Businesses?]. Hitelintézeti szemle 13(4): 102-126. 
Block, J. H. - Colombo, M. G. - Cumming, D. J. - Vismara, S. (2017): New Players In Entrepreneurial Finance and Why They are There. Small Business Economics 50(2): 239-250.

Buttice, V. - Colombo, M. G. - Wright, M. (2017): Serial Crowdfunding, Social Capital, and Project Success. Entrepreneurship Theory \& Practice 41(2): 183-207.

Chen, S. - Sunil, T. - Chiranjeev, K. (2016): What Really Makes A Promotional Campaign Succeed on a Crowdfunding Platform? Guilt, Utilitarian Products, Emotional Messaging, and Fewer but Meaningful Rewards, Drive Donations. Journal of Advertising Research 56(1): 81-94.

Chen, Y. (2018): Blockchain Tokens and the Potential Democratization of Entrepreneurship and Innovation. Business Horizons 60(4): 567-575.

Cox, J. - Nguyen, T. (2018): Does the Crowd Mean Business? An Analysis of Rewards-Based Crowdfunding as a Source of Finance for Start-Ups and Small Businesses. Journal of Small Businesses and Enterprise Development 25(1): 147-162.

CrowdBerkeley (2018): https://funginstitute.berkeley.edu/research/crowdberkeley/, accessed: 10/03/2018.

CrowdExpert (2018): http://crowdexpert.com/crowdfunding-industry-statistics/, accessed: 10/03/2018.

Csontos, R. S. - Szabó, Z. R. (2018): A versengés új színterei: platformok stratégiaimenedzsmentmegközelítésböl [New Scenes of Competition: Platforms from a Strategic Management Approach]. Vezetéstudomány/Budapest Management Review 49(9): 57-69.

Danmayr, F. (2014): Archetypes of Crowdfunding Platforms. A Multidimensional Comparison. Wiesbaden: Springer Gabler.

Durgula, J. - Majsa, I. - Kovács, T. (2017): Alternatív lehetőség startup-ok számára - a közösségi finanszírozás jellemzői és néhány hazai projekt esete. [Alternative Opportunity for Startups: The Characteristics of Crowdfunding and the Description of Some Hungarian Projects]. In: Resperger, R. (ed.): Geopolitikai Stratégiák Közép-Európában [Geopolitical Strategies in Central Europe]. Sopron: Soproni Egyetem Kiadó.

Elia, G. - Margherita, A. (2018): Assessing the Maturity of Crowdventuring for Corporate Entrepreneurship. Business Horizons 61(2): 271-283.

Fedorenko, I. - Berthon, P. - Rabinovich, T. (2017): Crowded Identity: Managing Crowdsourcing Initiatives to Maximize Value for Participants Through Identity Creation. Business Horizons 60(2): 155-165.

Ferke, J. - Budai, J. - Balassa, T. - Simon, B. (2016): Venture Capital and Private Equity - Tókebevonási Kalauz. [Venture Capital and Private Equity - Fundraising Guide]. Budapest: HVCA.

Fleming, L. - Sorenson, O. (2016): Financing by and for the Masses: An Introduction to the Special Issue on Crowdfunding. California Management Review 58(2): 5-19.

Forbes, H. (2015): Understanding Crowdfunding: Constructing A Guidance Tool for Crowdfunding Success. The University of Bath: Department of Mechanical Engineering.

Forbes, H. - Schaefer, D. (2017): Guidelines for Successful Crowdfunding. Procedia CIRP 60: 398-403.

Gábossy, Á. (2016): Újabb irányzatok a közösségi finanszírozásban. [New Trends in Crowdfunding] Pénzügyi Szemle (4): 544-555.

Haas-Berkeley Crowdfunding Website (2016): https://crowdfunding.haas.berkeley.edu, accessed 10/03/2018.

Harriet, L. - Abdoune, R. - Bentebbaa, S. (2017): La perception de l'equity crowdfunding par les dirigeants de PME en France. Revue Management \& Avenir 93: 15-35.

Hossain, M. - Oparaocha, G. O. (2017): Crowdfunding: Motives, Definitions, Typology and Ethical Challenges. Entrepreneurship Research Journal 7(2): 1-14.

infoDev (2013): Crowdfunding's Potential for the Developing World. Finance and Private Sector Development Department. Washington, DC: World Bank. 
Juhász, Z. (2018): A közösségi finanszírozás csoportalakító szerepe. [The Group-Forming Role of Crowdfunding] In Tóth, A. (ed.): Gazdaság, Társadalom V. - Társadalmi Csoportok Jövője. [Economy, Society V. - The Future of Social Groups]. Budapest: Arisztotelész Bt.

Katona, V. N. (2019): Role and Positioning of Reward Based Crowdfunding in the Funding of Technological Innovation Projects - Viewpoint of Entrepreneurial Financing Experts. Vezetéstudomány Budapest Management Review 50(5): 13-24.

Kuti, M. - Bedő, Zs. (2016): Az egyetemi vállalkozói ökoszisztémába ágyazott közösségi finanszírozás. [Crowdfunding Embedded in the University Entrepreneurial Ecosystem]. Vezetéstudomány - Budapest Management Review 47(2): 45-52.

Kuti, M. - Bedö, Zs. (2018): Az egyetemi központú vállalkozói ökoszisztéma és a közösségi finanszírozás kapcsolata. [The Relationship Between the University-Centered Entrepreneurial Ecosystem and Crowdfunding]. Vezetéstudomány - Budapest Management Review 49(2): 45-52.

Kuti, M. - Bedő, Zs. - Geiszl, D. (2017): A tulajdonosi tőke alapú közösségi finanszírozás. [Equity-Based Community Financing]. Hitelintézeti Szemle 16(4): 187-200.

Kuti, M. - Galambosné Tiszberger, M. - Czigler, E. (2018): Magyarországról indított közösségi finanszírozású kampányok - A Kickstarter-platform esete. [Community-Funded Campaigns from Hungary - The Case of the Kickstarter Platform]. Közgazdasági Szemle 65: 206-225.

Kuti, M. - Hornyák, M. (2017): A technológiai közösségi finanszírozás trendjei [The Trends of Technology Crowdfunding]. Külgazdaság 61(5-6): 28-45.

Kuti, M. - Madarász, G. (2014): A közösségi finanszírozás. [Crowdfunding]. Pénzügyi Szemle 2014(3): 374385.

Lee, I - Shin, Y. J. (2018): Fintech: Ecosystem, Business Models, Investment Decisions, and Challenges. Business Horizons 61: 35-46.

Mollick, E. (2014): The Dynamics of Crowdfunding: An Exploratory Study. Journal of Business Venturing 29: 1-16.

Mulcahy, D. (2013): 6 Myths About Venture Capitalists. Harvard Business Review, May.

Ordanini, A. - Miceli, L. - Pizzetti, M. - Parasuraman, A. (2011): Crowd-Funding: Transforming Customers into Investors Through Innovative Service Platforms. Journal of Service Management 22(4): 443-470.

Osterwalder, A. - Pigneur, Y. (2010): Business Model Generation. New Jersey: John Wiley \& Sons.

Paschen, J. (2017): Choose Wisely: Crowdfunding Through the Stages of the Startup Life Cycle. Business Horizons 60: 179-188.

Roma, P - Petruzzelli, A. M. - Perrone, G. (2017): From the Crowd to the Market: The Role of RewardBased Crowdfunding Performance in Attracting Professional Investors. Research Policy 46: 1606-1628.

Scholz, N. (2015): The Relevance of Crowdfunding. The Impact on the Innovation Process of Small Entrepreneurial Firms. Manchester, UK: Springer Gabler.

Schwienbacher, A. - Larralde, B. (2012): Alternative Types of Entrepreneurial Finance. In: Cumming, D. (ed.): Handbook of Entrepreneurial Finance. Oxford: Oxford University Press.

Stemler, A. R. (2013): The JOBS Act and Crowdfunding: Harnessing the Power - and Money - of the Masses. Business Horizons 56: 271-275.

Tauscher, K. (2017): Leveraging Collective Intelligence: How to Design and Manage Crowd-Based Business Models. Business Horizons 60: 237-245.

Turan, S. S. (2015): Financial Innovation - Crowdfunding: Friend or Foe? Procedia - Social and Behavioral Sciences 195: 353-362.

Valanciene, L. - Jegeleviciute, S. (2014): Crowdfunding for Creating Value: Stakeholder Approach. Procedia - Social and Behavioral Sciences 156: 599-604. 
Vasileiadou, E. - Huijben, J.C.C.M. - Raven, R.P.J.M. (2015): Three is a Crowd? Exploring the Potential of Crowdfunding for Renewable Energy in The Netherlands. Journal of Cleaner Production 128: 142-155.

Wilson, M. - Robson, K. - Botha, E. (2017): Crowdsourcing in Time of Empowered Stakeholders: Lessons from Crowdsourcing Campaigns. Business Horizons 60: 247-253.

Open Access. This is an open-access article distributed under the terms of the Creative Commons Attribution 4.0 International License (https://creativecommons.org/licenses/by/4.0/), which permits unrestricted use, distribution, and reproduction in any medium, provided the original author and source are credited, a link to the CC License is provided, and changes - if any - are indicated. (SID_1) 